\title{
PENGARUH KECAKAPAN MANAJERIAL TERHADAP MANAJEMEN LABA AKRUAL DAN RIIL
}

\author{
Melinda Majid ${ }^{1}$, Shanti Lysandra ${ }^{2}$, Indah Masri ${ }^{3}$, Widyaningsih Azizah ${ }^{4}$ \\ Fakultas Ekonomi dan Bisnis Universitas Pancasila \\ melindamajid04@gmail.com $^{1}$
}

\begin{abstract}
The purpose of this research is to examine the effect of managerial ability on accrual and real earnings management. The population in this research is companies listed in LQ45 index for the year 2016-2018. The sample is determined by purposive sampling method and obtained a sample of 25 companies. The type of data is secondary data obtained from www.idx.co.id. The analytical technique used in this research is panel data regression analysis and processed using the Eviews 9.0 program. The results indicated that managerial ability which is measured using Data Envelopment Analysis (DEA) has positive effect on accrual earnings management. However, managerial ability has negative effect on real earnings management. This is because there is a substitution relationship between accrual and real earnings management, when accrual earnings management increases, real earnings management will decrease.
\end{abstract}

Keywords : Accrual Earnings Management, Real Earnings Management, Managerial Ability, Data Envelopment Analysis (DEA)

\section{PENDAHULUAN}

Laba (earnings) dianggap sebagai informasi penting yang menjadi pusat perhatian investor dalam pengambilan keputusan investasi. Informasi laba disajikan dalam laporan laba rugi. Namun seringkali investor mengabaikan bagaimana proses perusahaan dalam menghasilkan laba tersebut, sehingga memberikan kesempatan bagi manajer untuk melakukan praktik manajemen laba.

Manajemen laba merupakan proses untuk mengambil langkah tertentu yang disengaja dalam batas prinsip akuntansi berterima umum (PABU) untuk menghasilkan tingkat yang diinginkan dari laba yang dilaporkan. Pada sejumlah penelitian yang dilakukan oleh Wami (2014), Lidiawati dan Asyik (2016), dan Maulana (2017) membuktikan bahwa manajemen laba muncul karena adanya konflik antara pemegang saham (principal) dan manajer (agent) yang disebut teori agensi (agency theory). Konflik ini mengakibatkan muculnya kesenjangan informasi (asimetri informasi) sehingga memberi celah bagi manajer untuk melakukan tindakan oportunis. Manajer dapat memilih kebijakan akuntansi tertentu, dinaikkan maupun diturunkan sesuai dengan keinginannya (Yulivia, Muslim dan Fauziati, 2016).

Manajemen laba terdiri dari dua pendekatan yaitu manajemen laba akrual (accrual earnings management) dan manajemen laba riil (real earnings management). Manajer melakukan manajemen laba akrual dengan merekayasa discretionary accrual yang tidak berpengaruh terhadap arus kas secara langsung dan biasanya dilakukan pada akhir periode akuntansi ketika manajemen mengetahui bahwa target laba tidak tercapai. Sebagai contoh, untuk memperbesar laba manajer dapat menurunkan persentase biaya kerugian piutang yang mengakibatkan biaya kerugian piutang menjadi rendah (Azizah, 2017). Disisi lain, manajer melakukan manajemen laba riil melalui aktivitas operasional perusahaan selama periode akuntansi seperti memberi potongan harga, memperbesar jumlah produksi, dan menurunkan beban diskresioner.

Kasus manajemen laba telah banyak terjadi sejak beberapa tahun lalu baik di luar negeri maupun dalam negeri. Fenomena praktik manajemen laba menimbulkan kecurigaan terhadap manajer dan integritas akuntan. Kasus yang terjadi 
di luar negeri pada tahun 2015 yaitu pada perusahaan Toshiba yang menjadi pionir asal Jepang. Perusahaan ini telah beroperasi di berbagai industri, antara lain elektronik, infrastuktur, semikonduktor, alat-alat kesehatan dan peralatan rumah tangga dengan pendapatan penjualan mencapai lebih dri US\$ 63 miliar. Pada pembukuan per 31 Maret 2014 ditemukan 21 kasus terutama terkait pekerjaan konstruksi, dimana Toshiba mengumumkan kesalahan perhitungan sebesar 54,8 miliar yen sehingga Toshiba menunda mengumumkan laporan keuangannya. Setelah dilakukan pemeriksaan, dinyatakan bahwa Toshiba melakukan praktik manajemen laba dengan memperbesar laba sebesar US\$ 1,22 miliar selama beberapa tahun. Sedangkan pada kenyataannya, perusahaan tersebut merugi sejak tahun 2008 sehingga mengumumkan laba yang tidak sesuai dengan realita. Pada 1 September 2015, untuk yang kedua kalinya Toshiba menunda mengumumkan laporan keuangan karena ditemukan kesalahan dalam perhitungan akuntansi. Selama tahun 2015, saham Toshiba turun hingga 20 persen karena kasus-kasus yang mulai mencuat ke permukaan dan berisiko akan dihapus dari bursa saham. Dalam sepuluh tahun terakhir, Toshiba resmi menutup enam perusahaannya di Indonesia termasuk pabrik terbesarnya yang berlokasi di Cikarang. Pada tahun 2016, PT. Toshiba Consumer Product Indonesia telah diakuisisi oleh Skyworth Group asal China (http://finance.detik.com).

Kecakapan manajerial menjadi salah satu faktor yang penting dalam mempengaruhi praktik manajemen laba. Puspita dan Kusumaningtyas (2017) mengungkapkan bahwa kecakapan manajerial adalah suatu karakteristik personal atau keterampilan yang mendorong manajemen dalam mencapai kinerja yang tinggi. Manajer dianggap cakap apabila mampu meningkatkan nilai perusahaan melalui keputusan yang dibuatnya karena setiap keputusan manajemen memiliki dampak bagi perusahaan. Selain itu, manajer dikatakan cakap apabila mampu mendesain proses bisnis perusahaan sehingga mencapai tingkat efisiensi yang lebih tinggi. Perusahaan dikatakan efisien ketika keluaran (ouput) yang dihasilkan lebih besar dibandingkan masukan (input) yang digunakan. Manajer yang cakap memiliki integritas, kemampuan, serta pengalaman dalam mengelola bisnis perusahaan sehingga akan mudah mencapai laba yang optimal (Mukhtar, 2016).

Berdasarkan uraian diatas, penulis tertarik untuk menguji kembali faktor diatas yaitu kecakapan manajerial untuk mengetahui kepastian dari faktor tersebut dalam mempengaruhi manajemen laba akrual dan riil. Objek penelitian yang digunakan adalah perusahaan LQ45 yang terdaftar di Bursa Efek Indonesia (BEI) pada periode 2016-2018.

Dengan demikian, atas dasar penjelasan itulah penelitian ini dilakukan dengan mengambil judul "Pengaruh Kecakapan Manajerial Terhadap Manajemen Laba Akrual Dan Riil (Studi Empiris pada Perusahaan LQ45 yang Terdaftar di Bursa Efek Indonesia Periode 2016-2018)".

\section{KAJIAN PUSTAKA}

\section{Teori Agensi}

Teori agensi terfokus kepada dua pihak yaitu pemilik/pemegang saham (principal) dan manajer (agent). Hal penting dalam teori ini yaitu hubungan kontraktual antara pemilik dan manajer dimana pemilik memberikan kewenangan kepada manajer untuk mengelola perusahaan atas nama pemilik. Dengan adanya pemisahan kepemilikan dan pengelolaan perusahaan, akan mendorong pemilik dan manajer untuk mengoptimalkan kemakmurannya. Manajer sebagai pengelola perusahaan memiliki informasi yang lebih beragam tentang kondisi perusahaan sebenarnya serta prospek dimasa yang akan datang. Sedangkan pemilik memiliki informasi yang terbatas, sehingga adanya kesenjangan informasi (asimetri informasi). tersebut, mendorong manajer untuk berperilaku oportunis dalam mengungkapkan informasi mengenai perusahaan (Azizah, 2017).

\section{Manajemen Laba}

Manajemen laba merupakan tindakan manajer dalam merekayasa angka-angka laporan keuangan atau memanipulasi informasi laba yang diperoleh suatu perusahaan (Ponto dan Rasyid, 2017). Manajer dapat meratakan, menaikkan, atau menurunkan laba. Informasi laba sangat penting bagi investor sehingga memotivasi manajer untuk mempercantik laporan keuangan (window dressing) demi mendapatkan tujuan yang diharapkan walaupun merugikan pihak lain.

Secara umum definisi manajemen laba yaitu sebagai upaya manajer untuk mengintervensi atau mempengaruhi informasi-informasi yang disajikan dalam laporan keuangan dengan tujuan untuk mengelabui stakeholder yang ingin mengetahui kinerja dan kondisi perusahaan. Istilah intervensi dan mengelabui ini membuat beberapa pihak menilai manajemen laba sebagai tindakan 
kecurangan. Namun, pihak lainnya tetap menganggap bahwa manajemen laba bukanlah sebuah kecurangan karena intervensi manajemen dalam kerangka standar akuntansi yang masih menggunakan prosedur dan metode akuntansi yang diterima secara umum. Manajer melakukan praktik manajemen laba agar laporan keuangan perusahaan terlihat lebih baik dengan mempercantik laporan keuangan, khususnya pada angka yang berada di paling bawah yaitu laba (Kodriyah dan Putri, 2019).

Gunny (2010) mengklasifikasikan manajemen laba menjadi dua kategori, yaitu:

1. Manajemen Laba Akrual

Manajemen laba akrual dilakukan dengan merekayasa komponen akrual dalam laporan keuangan, sebab akrual adalah komponen yang mudah untuk direkayasa sesuai dengan keinginan pribadi. Alasannya, komponen akrual merupakan komponen yang tidak memerlukan bukti kas secara fisik sehingga upaya merekayasa besar kecilnya komponen akrual tidak harus disertai dengan kas yang diterima atau dikeluarkan perusahaan (Sulistyanto, 2008:161). Sebagai contoh, untuk memperbesar laba, perusahaan dapat mengakui barang yang dititipkan sebagai barang konsinyasi atau barang yang dikeluarkan sebagai barang terjual. Atau sebaliknya, untuk memperkecil laba, perusahaan dapat menunda mengakui pendapatan periode berjalan menjadi pendapatan periode berikutnya. Selain itu, perusahaan juga dapat mengakui laba periode berjalan menjadi lebih kecil atau besar dari laba yang sesungguhnya dengan cara mengatur besar kecilnya suatu biaya.

2. Manajemen Laba Riil

Manajemen laba melalui aktivitas riil merujuk pada rekayasa angka laba yang dilakukan melalui aktivitas-aktivitas yang berasal dari kegiatan bisnis normal atau yang berhubungan dengan kegiatan operasional, misalnya menunda kegiatan promosi produk atau mempercepat penjualan dengan memberikan diskon besarbesaran. Roychowdhury (2006) menyatakan bahwa praktik manajemen laba riil dapat dilakukan menggunakan tiga metode sebagai berikut:

a. Memanipulasi Penjualan (Sales Manipulation)

Memanipulasi penjualan atau meningkatkan penjualan secara tidak wajar dilakukan dengan menawarkan diskon harga atau syarat kredit yang ringan. Akibatnya, manajer dapat meningkatkan penjualan selama tahun berjalan sehingga akan meningkatkan laba kotornya. Pemberian potongan harga akan meningkatkan volume penjualan sehingga target laba jangka pendek dapat tercapai dan kinerja manajer akan terlihat baik sehingga manajer dapat menerima bonus (Muktar, 2016).

b. Mengurangi Biaya Diskresioner (Reduction of Discretionary Expenditures)

Biaya diskresioner adalah biaya yang tidak berkaitan dengan ouput dan biaya yang output-nya tidak dapat dinyatakan dalam satuan moneter. Pengeluaran diskresioner seperti biaya riset dan pengembangan $(\mathrm{R} \& \mathrm{D})$, biaya iklan, biaya administrasi dan umum, serta biaya pemeliharaan dibebankan pada periode terjadinya. Dengan demikian, perusahaan dapat mengurangi biaya yang dilaporkan dan meningkatkan laba dengan mengurangi pengeluaran diskresioner.

c. Produksi yang Berlebihan (Overproduction)

Metode dalam praktik manajemen laba riil yang ketiga adalah dengan melakukan overproduction. Manajer akan memproduksi persediaan dalam skala yang lebih besar dari yang dibutuhkan untuk memenuhi permintaan yang diharapkan perusahaan. Teknik ini biasa dilakukan oleh sektor manufaktur untuk meningkatkan laba tahun berjalan. Dengan tingkat produksi yang lebih tinggi, biaya overhead tetap per unit semakin kecil sehingga biaya per unitnya menjadi rendah. Oleh karena itu, biaya barang yang terjual lebih rendah sehingga perusahaan mendapat keuntungan operasi yang lebih baik.

\section{Kecakapan Manajerial}

Kunci kesuksesan sebuah perusahan yaitu kinerja manajer yang mampu mendesain proses bisnis sehingga mencapai tingkat efisiensi yang tinggi. Perusahaan mencapai tingkat efisiensi ketika keluaran (output) lebih besar dari masukan (input) yang digunakan. Perusahaan dapat menggunakan sumber daya secara minimum guna mencapai hasil yang optimal. Disamping itu, kemampuan manajer dalam membuat keputusan-keputusan yang dapat memberi nilai tambah bagi perusahaan serta mampu mengomunikasikan kinerja perusahaan kepada stakeholders (Mukhtar, 2016).

Manajer yang memiliki kapablitas dan keahlian yang baik dalam mengelola bisnis perusahaan dapat dikatakan sebagai manajer yang cakap. Kecakapan manajerial adalah suatu karakteristik personal atau keterampilan yang mendorong manajemen dalam mencapai kinerja yang tinggi (Puspita dan Kusumaningtyas, 2017). Keterampilan yang harus dimiliki manajer untuk 
mencapai kinerja yang tinggi antara lain keterampilan konseptual, teknis, komunikasi, manajemen waktu, membuat keputusan, serta kepemimpinan. Keterampilan tersebut muncul karena manajer yang cakap memiliki tingkat intelegensi dan pendidikan yang tinggi. Semakin tinggi tingkat intelegensi dan pendidikan seorang manajer maka semakin efisien dan mampu dalam membuat keputusan yang dapat menambah nilai perusahaan. Selain itu, pengalaman juga menjadi salah satu indikator yang menentukan tingkat kecakapan seorang manajer. Semakin berpengalaman seorang manajer maka semakin terampil dalam mendesain proses bisnis perusahaan.

\section{Data Envelopment Analysis (DEA)}

Mulyadi (2016:1-2) menyatakan bahwa data envelopment analysis (DEA) adalah aplikasi program linier untuk menilai efisiensi dari unit sejenis yang mempunyai tujuan yang sama, unit dapat berupa bank, perusahaan, cabang, unit kerja atau produk. Nilai efisiensi diukur dengan membagi antara total output dengan total input. Input adalah sumber daya yang digunakan dalam operasional perusahaan sedangkan output adalah hasil yang diperoleh dari penggunaan sumber daya tersebut. Semakin tinggi input suatu perusahaan maka skor DEA akan semakin rendah dan perusahaan dinyatakan kurang efisien. Sebaliknya semakin tinggi output maka skor DEA semakin tinggi dan perusahaan dinyatakan semakin efisien.

DEA bermaksud mengukur tingkat efisiensi relatif dari unit-unit yang sejenis yang disebut decision making units (DMU) dan yang dimaksud sejenis adalah sama dalam pola proses input dan ouputnya. Efisiensi relatif didefinisikan sebagai rasio dari total output tertimbang dibagi total input tertimbangnya. Inti dari DEA adalah menentukan bobot untuk setiap input dan ouput. Bobot tersebut memiliki sifat: (1) tidak bernilai negative, dan (2) bersifat universal, artinya setiap DMU dalam sampel harus dapat menggunakan seperangkat bobot yang sama untuk mengevaluasi rasionya (total weighted ouput/input) dan rasio tersebut tidak boleh lebih dari 1 (total weighted output/total weighted input $\leq 1$ ).

Variabel yang diuji dalam penelitian ini yaitu kecakapan manajerial. Hubungan diantara variabel tersebut dapat digambarkan dalam kerangka pemikiran sebagai berikut:

\section{Kerangka Pemikiran}

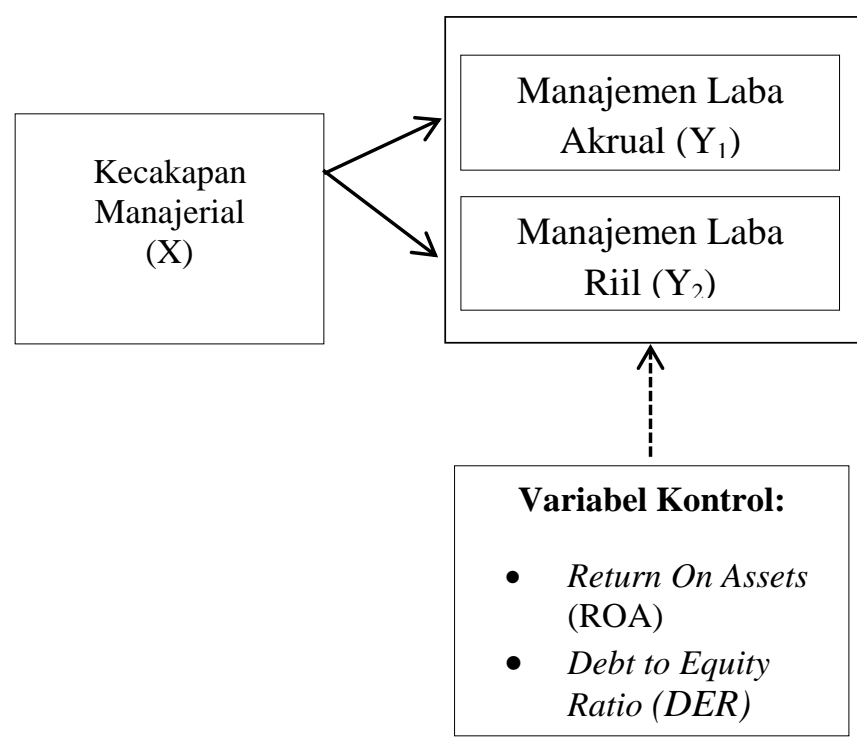

Sumber : data diolah peneliti

\section{Pengembangan Hipotesis \\ Pengaruh Kecakapan Manajerial terhadap Manajemen Laba Akrual}

Sebagai pihak yang bertanggung jawab untuk menyampaikan informasi laporan keuangan kepada stakeholders, manajer memiliki keleluasaan dalam mengatur laba. Manajer dapat memilih kebijakan akuntansi yang menguntungkan dalam memenuhi kontrak untuk memaksimumkan kemakmuran dirinya melalui manajemen laba. Manajer dianggap cakap apabila mampu meningkatkan nilai perusahaan dan mendesain proses bisnis menuju tingkat efisiensi yang tinggi melalui keputusan yang dibuatnya. Hal ini dikarenakan manajer memiliki tingkat intelegensi, integritas, kemampuan, serta pengalaman yang baik dalam mengelola bisnis sehingga perusahaan dapat mencapai laba yang optimal. Keahlian tersebut dapat dimanfaatkan oleh manajer untuk melakukan tindakan oportunis seperti memanipulasi informasi yang akan disajikan dalam laporan keuangan. Manajer yang cakap akan merekayasa komponen akrual dalam laporan keuangan, sebab akrual adalah komponen yang mudah untuk direkayasa sesuai dengan keinginan pribadi. Manajer akan merekayasa discretionary accrual yang tidak berpengaruh terhadap arus kas secara langsung dan biasanya dilakukan pada akhir periode akuntansi ketika manajemen mengetahui bahwa target laba tidak tercapai.

Penelitian Kirana, Hasan, dan Hardi (2016) berhasil membuktikan bahwa kecakapan manajerial berpengaruh positif terhadap praktik manajemen laba. Hal ini dikarenakan manajer yang cakap dapat 
memanfaatkan kewenangan untuk memilih kebijakan dalam proses penyusunan laporan keuangan yang memungkinkan manajer melakukan manipulasi informasi laba. Semakin cakap seorang manajer maka semakin tinggi manajemen laba yang dilakukan perusahaan. Hasil ini konsisten dengan penelitian yang dilakukan oleh Puspita dan Kusumaningtyas (2017), dimana manajer yang memiliki tingkat kecakapan yang tinggi akan lebih terampil dalam mengolah informasi sehingga memberi peluang untuk melakukan praktik manajemen laba. Berdasarkan hasil penelitian terdahulu tersebut, maka hipotesis pertama yang diajukan adalah sebagai berikut:

$H_{1}$ : Kecakapan manajerial berpengaruh positif terhadap manajemen laba akrual.

\section{Pengaruh Kecakapan Manajerial terhadap Manajemen Laba Riil}

Manajer yang cakap dapat mengatur laba yang dilaporkan dengan cara melakukanc tindakan yang menyimpang dari praktik operasi normal perusahaan. Manajemen laba riil dapat dilakukan dengan memanipulasi aktivitas perusahaan seharihari sehingga praktik ini dapat dilakukan kapan saja sepanjang periode akuntansi berjalan dengan tujuan untuk mencapai target laba tertentu. Roychowdhury (2006) menyatakan bahwa praktik manajemen laba riil dapat dilakukan menggunakan tiga metode diantaranya dengan memanipulasi penjualan (sales manipulation), mengurangi biaya diskresioner (reduction of discretionary expenditures) dan produksi yang berlebihan (overproduction). Auditor dan pemerintah akan sulit mendeteksi apakah tindakan manajer merupakan strategi perusahaan atau tindakan oportunis. Hal ini tentunya dimanfaatkan oleh manajer sebagai peluang agar dapat mencapai target laba yang diharapkan. Manajer yang cakap mampu mencapai laba yang optimal melalui keputusan bisnis yang dibuatnya. Manajer yang memiliki keahlian dan tingkat intelegensi yang tinggi dapat memanfaatkan peluang tersebut dengan menyalahgunakan dan memanipulasi informasi yang tidak diketahui oleh pemilik seperti manipulasi laporan keuangan.

Penelitian Mukhtar (2016) membuktikan bahwa kecakapan manajerial berpengaruh negatif terhadap manajemen laba riil melalui arus kas operasi abnormal, arus kas produksi abnormal, dan biaya diskresioner abnormal. Semakin cakap seorang manajer dalam perusahaan cenderung untuk tidak melakukan praktik manajemen laba riil karena manajer akan meningkatkan kualitas kinerja dengan memanfaatkan sumber daya perusahaan baik melalui arus kas operasi abnormal, arus kas produksi abnormal, dan biaya diskresioner abnormal. Hal ini karena seorang manajer sebagai pengelola perusahaan ingin menyajikan laporan keuangan yang lebih baik daripada harus melakukan praktik manajemen laba yang memiliki dampak buruk bagi perusahaan. Berdasarkan hasil penelitian terdahulu tersebut, maka hipotesis kedua yang diajukan adalah sebagai berikut:

$\mathrm{H}_{2}$ : Kecakapan manajerial berpengaruh negatif terhadap manajemen laba riil.

\section{METODE PENELITIAN}

Metode penelitian yang digunakan dalam penelitian ini adalah studi empiris dengan pendekatan deskriptif kuantitatif. Metode deskriptif kuantitatif adalah teknik pengumpulan, pengelolaan, penyederhanaan, penyajian, dan analisis data kuantitatif secara deskriptif agar dapat memberikan gambaran yang sistematis tentang suatu fenomena. Metode ini disebut metode kuantitatif karena data penelitian berupa angkaangka dan analisis menggunakan statistik. Data yang digunakan dalam penelitian ini adalah data sekunder yang diperoleh dari situs resmi Bursa Efek Indonesia (www.idx.co.id).

\section{Populasi dan Sampel}

Populasi dalam penelitian ini yaitu perusahaan LQ45 yang terdaftar di Bursa Efek Indonesia (BEI) pada tahun 2016-2018. Teknik pengumpulan sampel yang digunakan dalam penelitian ini adalah purposive sampling, metode pengambilan sampel yang menggunakan kriteria tertentu sesuai tujuan penelitian. Adapun kriteria sampel yang akan digunakan adalah sebagai berikut:

1. Perusahaan yang terdaftar dalam indeks LQ45 selama periode 2016-2018, kecuali perusahaan yang masuk dalam jenis industri jasa keuangan, property dan real estate.

2. Perusahaan yang berturut-turut selama 3 (tiga) tahun terdaftar di indeks LQ45 selama tahun 2016-2018.

3. Perusahaan LQ45 yang menerbitkan laporan tahunan secara rutin dan lengkap di BEI pada tahun 2016-2018.

4. Data yang tersedia lengkap baik data mengenai indikator kecakapan manajerial dan data yang diperlukan untuk mendeteksi manajemen laba akrual dan riil. 


\section{Variabel Penelitian}

Terdapat 3 (tiga) variabel yang akan diteliti dalam penelitian ini, yaitu kecakapan manajerial sebagai variabel independen, return on assets (ROA) dan debt to equity ratio (DER) sebagai variabel kontrol, serta manajemen laba akrual dan riil sebagai variabel dependen.

\section{Operasionalisasi Variabel}

\section{Kecakapan Manajerial (X)}

Kecakapan manajerial adalah keterampilan yang dimiliki oleh seorang manajer dalam mencapai kinerja yang tinggi. Penelitian ini menggunakan Data Envelopment Analysis (DEA). DEA mengukur tingkat efisiensi relatif dari unitunit sejenis yang disebut Decision Making Units (DMU). DMU dinilai efisien jika rasio perbandingan input dengan output sama dengan 1 atau $100 \%$, jika hasilnya kurang dari $100 \%$ maka tidak efisien.

Input dan output yang digunakan konsisten dengan penelitian sebelumnya (Isnugrahadi dan Kusuma, 2009; Mukhtar, 2016; Kodriyah dan Putri, 2019) dapat diuraikan sebagai berikut:

1. Ouput

Item yang menjadi ouput dalam penelitian ini adalah penjualan. Penjualan merefleksikan nilai nominal dari produk perusahaan yang merupakan output mendasar dari perusahaan.

2. Input

Item-item yang menjadi input dalam penelitian ini dapat dikelompokkan dalam dua faktor, yaitu faktor sumber daya (jumlah tenaga kerja dan total aset) dan faktor operasional (Days Sales Outstanding-DSO dan Days COGS in Inventory-DCI).

a. Jumlah Tenaga Kerja

Tenaga kerja merupakan faktor sumber daya yang berperan dalam operasional perusahaan misalnya dalam kegiatan produksi, penjualan, dan lain-lain. Umumnya untuk nilai penjualan tertentu, semakin kecil jumlah tenaga kerja dalam menghasilkan penjualan maka semakin efisien suatu perusahaan (Mukhtar, 2016).

b. Total Aset

Aset merupakan faktor sumber daya perusahaan yang sangat penting dalam menghasilkan output (penjualan). Manajer dianggap cakap jika mampu mengelola besaran aset untuk menghasilkan penjualan yang maksimum (Kodriyah dan Putri, 2019).

c. Days Sales Outstanding (DSO)

DSO adalah nama lain dari average collection period (ACP) yang digunakan untuk mengukur waktu yang diperlukan perusahaan dalam mengumpulkan kas (dinyatakan dalam satuan hari). Manajer yang cakap mampu mengumpulkan kas dengan cepat. Jika semakin cepat, maka perusahaan dapat menginvestasikan kembali uang tersebut dengan cepat untuk menghasilkan penjualan yang maksimum. DSO dapat dirumuskan sebagai berikut:

$$
\text { DSO }=\frac{\text { Receivables }}{\text { Sales }} \times 365 \text { days }
$$

d. Days Cost of Goods Sold in Inventory (DCI)

DCI atau dikenal dengan Days Sales in Inventory (DSI) digunakan untuk mengukur waktu perputaran persediaan perusahaan untuk menghasilkan penjualan yang dinyatakan dalam satuan hari Perusahaan yang dapat menghasilkan perputaran persediaan yang cepat menunjukkan pengelolaan perusahaan oleh manajer yang cakap. DCI dapat dirumuskan sebagai berikut:

$$
\text { DCI }=\frac{\text { Inventory }}{\text { COGS }} \times 365 \text { days }
$$

Model yang digunakan untuk menghitung efisiensi dengan menggunakan pendekatan DEA sebagai berikut:

$$
\operatorname{MAX} \theta=\frac{\sum_{\mathrm{l}-1}^{\mathrm{s}} \text { Ui Yik }}{\sum_{\mathrm{j}-1}^{\mathrm{m}} \mathrm{Vj} \mathrm{Xjk}}
$$

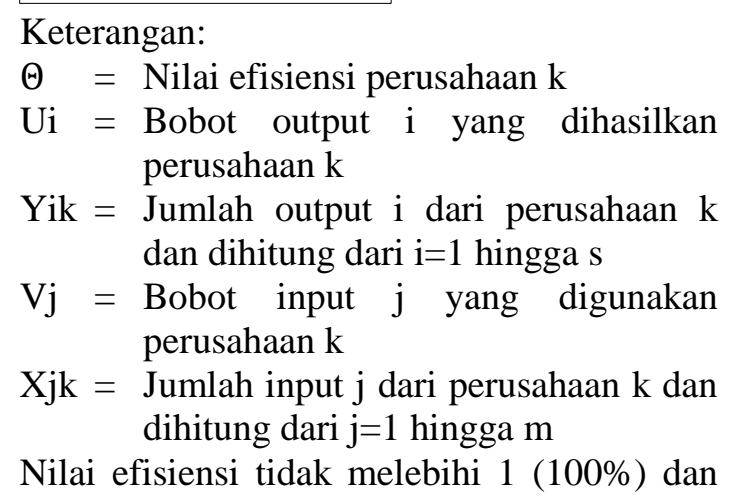
input serta ouput yang dianalisis harus positif. Dengan kata lain perusahaan tidak melakukan pemborosan sumber daya jika bernilai 1 (100\%), sebaliknya jika nilainya $0 \leq \frac{\text { Total Output }}{\text { Total Input }} \leq 1$, maka perusahaan dinilai inefisien dalam mengelola sumber daya yang tersedia. Dalam penelitian ini untuk mempermudah perhitungan efisiensi dengan pendekatan DEA, peneliti menggunakan software DEAP versi 2.1 .

\section{Variabel Kontrol (C)}

Dalam penelitian ini menggunakan dua variable control, sebagai berikut: 


\section{Return On Assets $\left(\mathrm{C}_{1}\right)$}

Sukamulja (2019:98) menyatakan bahwa ROA menunjukkan kemampuan perusahaan dalam menghasilkan laba bersih atas aktivanya. Semakin besar angka ini, maka perusahaan semakin profitable, dan sebaliknya semakin kecil angka rasio ini maka perusahaan semakin tidak profitable. ROA dapat dirumuskan sebagai berikut:

$$
\text { ROA }=\frac{\text { Net Income }(\mathrm{EAT})}{\text { Total } \text { Assets }}
$$

\section{Debt To Equity Ratio $\left(\mathrm{C}_{2}\right)$}

Kasmir (2019:159) menyatakan bahwa DER merupakan rasio yang digunakan untuk menilai utang dengan ekuitas. Rasio ini berguna untuk mengetahui jumlah dana yang disediakan peminjam (kreditor) dengan pemilik perusahaan. Dengan kata lain, rasio ini berfungsi untuk mengetahui setiap rupiah modal sendiri yang dijadikan untuk jaminan utang. Rumus untuk mencari debt to equity ratio dapat digunakan perbandingan antara total utang dengan total ekuitas sebagai berikut.

$$
\text { DER }=\frac{\text { Total Debt }}{\text { Total Equity) }}
$$

\section{Manajemen Laba Akrual ( $\left.\mathbf{Y}_{1}\right)$}

Manajemen laba akrual merupakan upaya manajer dalam mengaburkan atau menutupi keadaan perusahaan yang sebenarnya melalui akun diskresionari akrual (discretionary accruals) berdasarkan fleksibilitas yang diberikan kepada manajer dalam memilih berbagai prosedur dan metode akuntansi yang akan diterapkan perusahaan guna mencapai tujuan yang diharapkan. Penelitian ini menggunakan discretionary accruals sebagai proksi manajemen laba akrual. Mengacu pada penelitian Cohen et al. (2008) yang merupakan modifikasi dari Jones Model (Dechow et al., 1995) formula yang digunakan yaitu:

$$
\begin{gathered}
\frac{T A_{i t}}{\text { Assets }_{i, t-1}}=k_{1} \frac{1}{\operatorname{Assets}_{i, t-1}}+k_{2} \frac{\left(\Delta R E V_{i t-1}-\Delta A R_{i t-1}\right)}{\operatorname{Assets}_{i, t-1}} \\
+k_{3} \frac{P P E_{i t}}{\operatorname{Assets}_{i, t-1}}+\varepsilon_{\mathrm{it}}
\end{gathered}
$$

Nilai residual dari estimasi diatas diperoleh dari hasil regresi per tahun yang merupakan discretionary accruals untuk setiap observasi.

Keterangan:

$\mathrm{TA}_{\text {it }}=$ Total akrual perusahaan i pada tahun $\mathrm{t}$ (dimana $\mathrm{TA}_{\mathrm{it}}=$ Laba tahun berjalan Aliran kas dari kegiatan operasi)

Assets $_{\mathrm{i}, \mathrm{t}-1} \quad=$ Total asset perusahaan i pada tahun t-1

$\Delta \operatorname{Rev}_{\text {it }} \quad=$ Perubahan pendapatan perusahaan $\mathrm{i}$ pada tahun $\mathrm{t}$
$\Delta \mathrm{AR}_{\mathrm{it}}$

$=$ Perubahan piutang perusahaan $\mathrm{i}$ pada tahun $\mathrm{t}$

$\mathrm{PPE}_{\mathrm{it}} \quad=$ Property, Plant, and Equipment perusahaan i pada tahun $\mathrm{t}$

$\varepsilon_{\mathrm{it}}$

= Error term perusahaan i pada tahun $\mathrm{t}$

\section{Manajemen Laba Riil $\left(\mathbf{Y}_{2}\right)$}

Manajemen laba riil dilakukan dengan merekayasa angka laba melalui aktivitas operasional perusahaan yang dapat dilakukan kapan saja selama periode akuntansi. Penelitian ini konsisten dengan penelitian sebelumnya (Cohen \& Zarowin, 2010; Zang, 2012; Ge \& Kim, 2014; Azizah, 2017; Masri, 2018), untuk menghitung tiga proksi manajemen laba riil dirumuskan sebagai berikut:

1. Untuk mengestimasi arus kas kegiatan operasi normal (R_CFO)

$$
\begin{gathered}
\frac{\text { CFO }_{i t}}{\text { Assets }_{i, t-1}}=k_{1} \frac{1}{\text { Assets }_{i, t-1}}+k_{2} \frac{\text { Sales }_{i t}}{\text { Assets }_{i, t-1}} \\
+k_{3} \frac{\Delta \text { Sale }_{\mathrm{it}}}{\text { Assets }_{i, t-1}}+\varepsilon_{\mathrm{it}}
\end{gathered}
$$

Keterangan:

$\mathrm{CFO}_{\mathrm{it}} /$ Assets $_{\mathrm{i}, \mathrm{t}-}=$ Aliran kas dari kegiatan operasi (cash flow from operations) perusahaan i pada tahun $\mathrm{t}$ yang diskala dengan total asset perusahaan i pada tahun t1.

$\mathrm{k}_{1}\left(1 /\right.$ Asset $\left._{\mathrm{i}, \mathrm{t}-1}\right) \quad=\quad$ Intersep yang diskala dengan total aset perusahaan i pada tahun t1

$\mathrm{k}_{2}\left(\right.$ Sales $_{\mathrm{it}} /$ Assets $\left._{\mathrm{i}, \mathrm{t}-\mathrm{l}}\right)=$ Intersep penjualan bersih perusahaan i pada tahun $t$ yang diskala dengan total asset perusahaan i pada tahun $\mathrm{t}-1$.

$\mathrm{k}_{3}\left(\Delta\right.$ Sales $_{\mathrm{it}} /$ Assets $\left._{\mathrm{i.t}-1}\right)=$ Intersep perubahan penjualan perusahaan i pada tahun $t$ yang diskala dengan total asset perusahaan i pada tahun t1.

$\varepsilon_{\mathrm{it}} \quad=$ Error term perusahaan $\mathrm{i}$ pada tahun $\mathrm{t}$.

2. Untuk mengestimasi biaya produksi normal (R_PROD) 


$$
\begin{aligned}
\frac{\text { Prod }_{i t}}{\text { Assets }_{i, t-1}}=k_{1} & \frac{1}{\text { Assets }_{i, t-1}}+k_{2} \frac{\text { Sales }_{i t}}{\text { Assets }_{i, t-1}} \\
& +k_{3} \frac{\Delta \text { Sale }_{\mathrm{it}}}{\text { Assets }_{i, t-1}}+k_{4} \frac{\Delta \text { Sales }_{\mathrm{it}-1}}{\text { Assets }_{i, t-1}}+\varepsilon_{\mathrm{it}}
\end{aligned}
$$

Keterangan:

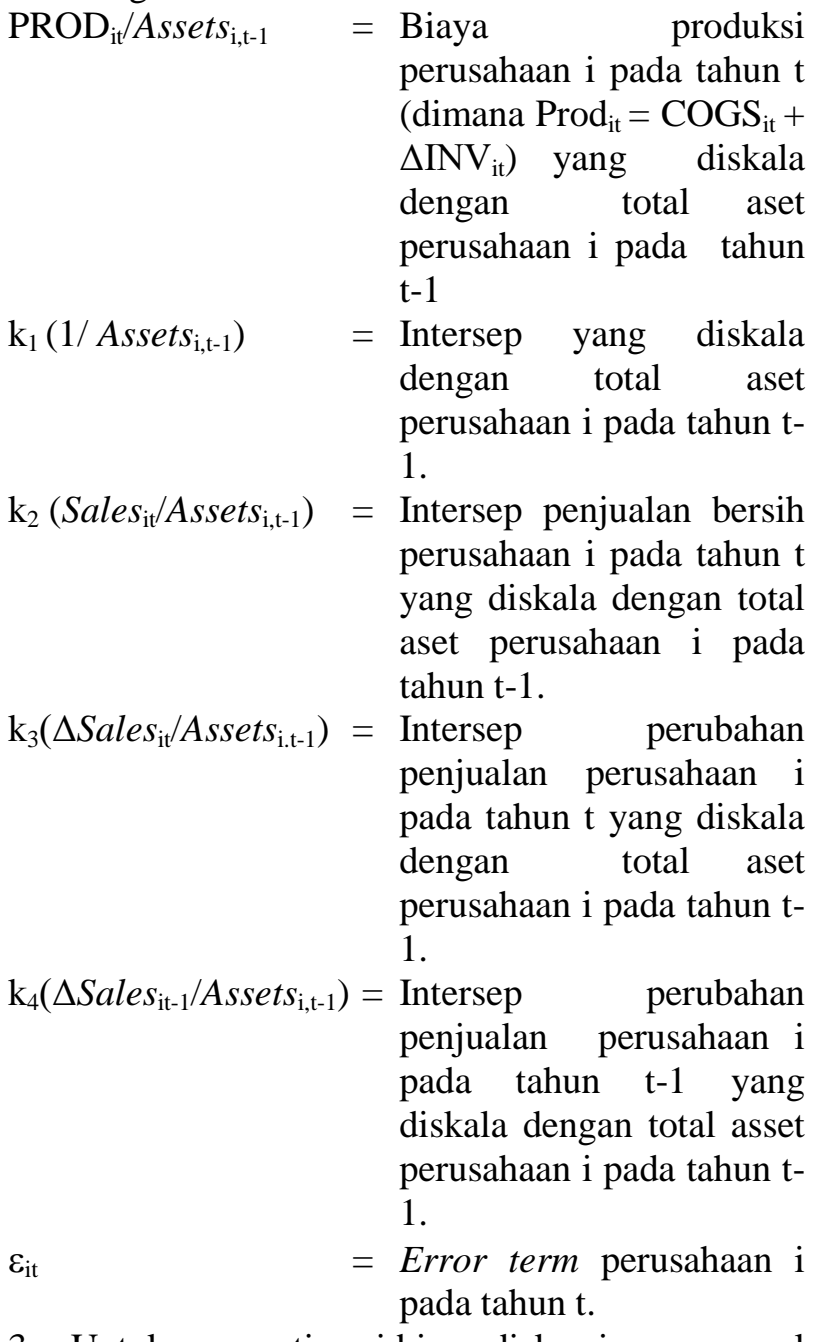

3. Untuk mengestimasi biaya diskresioner normal (R_DISX)

$$
\frac{\text { DiscExp }_{i t}}{\text { Assets }_{i+-1}}=k_{1} \frac{1}{\text { Assets }_{i+-1}}+k_{2} \frac{\text { Sales }_{i t-1}}{\text { Assets }_{i+-1}}+\varepsilon_{\mathrm{it}}
$$

Keterangan:

DiscExp $_{\text {it }} /$ Assets $_{\text {it-1 }}=$ Jumlah biaya diskresioner (biaya iklan ditambah biya riset dan pengembangan ditambah biaya penjualan, administrasi dan umum) perusahaan i pada tahun $\mathrm{t}$ 1.

4. Menghitung manajemen laba riil (RM_PROXY)

R_CFO, R_PROD, dan R_DISX merupakan tiga proksi manajemen laba riil. Nilai residual dari estimasi ketiga proksi tersebut diperoleh dari hasil regresi per tahun lalu nilai R_CFO dan R_DISX dikalikan -1 dan ketiganya dijumlahkan sehingga dihasilkan nilai manajemen laba riil (RM_PROXY).

\section{Model Penelitian}

Model penelitian dengan analisis regresi data panel yang berdasarkan perumusan dan tujuan penelitian ditulis sebagai berikut:

$$
\begin{aligned}
& Y_{1}=\alpha+\beta_{1} X_{1}+\beta_{2} C_{1}+\beta_{3} C_{2}+\varepsilon \\
& Y_{2}=\alpha+\beta_{1} X_{1}+\beta_{2} C_{1}+\beta_{3} C_{2}+\varepsilon
\end{aligned}
$$

Dimana:

$\mathrm{Y}_{1} \quad=$ Manajemen laba akrual

$\mathrm{Y}_{2}=$ Manajemen laba riil

$\alpha \quad=$ Konstanta

$\beta_{1}, \beta_{2}, \beta_{3}=$ Koefisien regresi

$\mathrm{X}_{1} \quad=$ Kecakapan manajerial

$\mathrm{C}_{1} \quad=$ Return on assets $(\mathrm{ROA})$

$\mathrm{C}_{2} \quad=$ Debt to equity ratio (DER)

$\varepsilon \quad=$ Residual

\section{HASIL PENELITIAN DAN PEMBAHASAN}

\begin{tabular}{|c|c|c|}
\hline No. & Keterangan & $\begin{array}{c}\text { Jumlah } \\
\text { Perusahaan }\end{array}$ \\
\hline 1 & $\begin{array}{l}\text { Perusahaan yang terdaftar } \\
\text { dalam indeks LQ45 selama } \\
\text { periode } 2016-2018\end{array}$ & 62 \\
\hline 2 & $\begin{array}{l}\text { Perusahaan yang berturut- } \\
\text { turut selama } 3 \text { (tiga) tahun } \\
\text { terdaftar di indeks LQ45 } \\
\text { selama tahun } 2016-2018\end{array}$ & $(28)$ \\
\hline 3 & $\begin{array}{l}\text { Perusahaan yang termasuk } \\
\text { dalam jenis industri jasa } \\
\text { keuangan }\end{array}$ & $(5)$ \\
\hline 4 & $\begin{array}{l}\text { Perusahaan yang termasuk } \\
\text { dalam jenis industri property } \\
\text { dan real estate }\end{array}$ & (2) \\
\hline 5 & Data tidak lengkap & (2) \\
\hline 6 & Jumlah sampel yang dipilih & 25 \\
\hline 7 & Tahun pengamatan & 3 \\
\hline \multicolumn{2}{|c|}{$\begin{array}{c}\text { Jumlah sampel total selama } \\
\text { periode pengamatan }\end{array}$} & 75 \\
\hline
\end{tabular}

\section{Hasil Penelitian}

Berdasarkan kriteria dalam sampel penelitian ini adalah sebagai berikut:

Kriteria Penentuan Sampel

\section{Analisis Statistik Deskriptif}

Statistik deskriptif digunakan untuk memberikan gambaran atau deskriptif data yang 
dilihat dari nilai minimum, nilai maksimum, nilai rata-rata (mean), dan standar deviasi.

\section{Statistik Deskriptif Penelitian}

\begin{tabular}{|c|c|c|c|c|c|}
\hline \multicolumn{6}{|c|}{ Sample: 20162018} \\
\hline & AEM & REM & KM & ROA & DER \\
\hline \multirow[b]{2}{*}{ Mean } & 0.00647 & 0.17336 & 0.70370 & 0.10023 & 1.22826 \\
\hline & 2 & 4 & 7 & 6 & 7 \\
\hline \multirow[b]{2}{*}{ Median } & $\begin{array}{c}- \\
0.00452\end{array}$ & 0.17339 & 0.77500 & 0.06760 & 0.87000 \\
\hline & 5 & 9 & 0 & 0 & 0 \\
\hline \multirow[b]{2}{*}{ Maximum } & 0.30403 & 0.89882 & 1.00000 & 0.46660 & 3.83000 \\
\hline & 9 & 9 & 0 & 0 & 0 \\
\hline \multirow[b]{2}{*}{ Minimum } & $\begin{array}{c}- \\
0.15115\end{array}$ & $\begin{array}{c}- \\
2.18227\end{array}$ & 0.14700 & 0.00090 & 0.15000 \\
\hline & 3 & 3 & 0 & 0 & 0 \\
\hline \multirow[b]{2}{*}{ Std. Dev. } & 0.07046 & 0.50561 & 0.29317 & 0.10082 & 0.98160 \\
\hline & 0 & 8 & 3 & 1 & 8 \\
\hline $\begin{array}{l}\text { Observatio } \\
\text { ns }\end{array}$ & 75 & 75 & 75 & 75 & 75 \\
\hline
\end{tabular}

Sumber: Hasil olah data dengan Eviews9, 2019

Berdasarkan data dari tabel diatas menampilkan hasil pengujian statistik deskriptif untuk variabel-variabel dalam penelitian, baik variabel independen yaitu kecakapan manajerial, variabel kontrol yaitu return on assets (ROA) dan debt to equity ratio (DER), maupun variabel dependen yaitu manajemen laba akrual dan riil. Hasil pengujian menunjukkan jumlah sampel (N) penelitian sebanyak 75 berdasarkan laporan tahunan perusahaan LQ45 yang terdaftar di BEI selama periode 2016-2018 dan telah memenuhi kriteria yang ditetapkan.

Hasil analisis statistik deskriptif terhadap manajemen laba akrual (accrual earnings management-AEM) menunjukkan nilai minimum sebesar -0.151153 yang dimiliki oleh PT. Matahari Department Store Tbk (LPPF) pada periode 2016 dan nilai maksimum sebesar 0.304039 yang dimiliki oleh PT. Waskita Karya (Persero) Tbk (WSKT) pada periode 2016. Dengan nilai rata-rata atau mean sebesar 0.006472 dan nilai standar deviasi sebesar 0,070460, menunjukkan bahwa data pada variabel manajemen laba akrual menyebar dan bervariatif karena standar deviasi lebih besar dari nilai rataratanya.

Hasil analisis statistik deskriptif terhadap variabel manajemen laba riil (real earnings management-REM) menunjukkan nilai minimum sebesar -2.182273 yang dimiliki oleh PT. Matahari Department Store Tbk (LPPF) pada periode 2016 dan nilai maksimum sebesar 0.898829 yang dimiliki oleh PT. Sri Rejeki Isman Tbk (SRIL) pada periode 2016. Dengan nilai rata-rata atau mean sebesar 0.173364 dan nilai standar deviasi sebesar sebesar 0.505618, menunjukkan bahwa data pada variabel manajemen laba riil menyebar dan bervariatif karena standar deviasi lebih besar dari nilai rata-ratanya karena standar deviasi lebih besar dari nilai rata-ratanya.

Hasil analisis statistik deskriptif terhadap kecakapan manajerial (KM) menunjukkan nilai minimum sebesar sebesar 0.147000 yang dimiliki oleh PT. Astra International Tbk (ASII) pada periode 2017 dan nilai maksimum sebesar 1.000000 yang dimiliki oleh PT. Adaro Energy Tbk (20162018), PT. AKR Corporindo Tbk (2018), PT. Aneka Tambang (Persero) Tbk (2018), PT. Astra International Tbk (2016 dan 2018), PT. Gudang Garam Tbk (2016-2018), PT. Indofood Sukses Makmur Tbk (2017-2018), PT. Jasa Marga Tbk (Persero) (2016-2018), PT. Matahari Department Store Tbk (2016-2018), PT. Perusahaan Gas Negara Tbk (2016-2018), PT. Unilever Indonesia Tbk (2016-2018), dan PT. Waskita Karya (Persero) Tbk (2017-2018). Dengan nilai rata-rata atau mean sebesar 0.703707 dan nilai standar deviasi sebesar 0.293173, menunjukkan bahwa data pada variabel kecakapan manajerial memiliki sebaran yang tidak begitu besar dan tidak bervariatif karena standar deviasi lebih kecil dari nilai rata-ratanya.

Hasil analisis statistik deskriptif terhadap return on assets (ROA) menunjukkan nilai minimum sebesar 0.000900 yang dimiliki oleh PT. Vale Indonesia Tbk (INCO) pada periode 2016 dan nilai maksimum sebesar 0.466600 yang dimiliki oleh PT. Unilever Indonesia Tbk (UNVR) pada periode 2018. Dengan nilai rata-rata atau mean sebesar 0.100236 dan nilai standar deviasi sebesar 0.100821 , menunjukkan bahwa data pada variabel return on assets (ROA) menyebar dan bervariatif karena standar deviasi lebih besar dari nilai rata-ratanya.

Hasil analisis statistik deskriptif terhadap debt to equity ratio (DER) menunjukkan nilai minimum sebesar 0.150000 yang dimiliki oleh PT. Indocement Tunggal Prakarsa Tbk (INTP) pada periode 2016 dan nilai maksimum sebesar 3.830000 yang dimiliki oleh PT. Adhi Karya (Persero) Tbk (ADHI) pada periode 2017. Dengan nilai mean sebesar 1.228267 dan nilai standar deviasi sebesar 0.981608, menunjukkan bahwa data pada variabel debt to equity ratio (DER) memiliki sebaran yang tidak begitu besar dan tidak bervariatif karena standar deviasi lebih kecil dari nilai rata-ratanya

\section{Analisis Regresi Data Panel}

Regresi data panel digunakan untuk memprediksi nilai dari variabel dependen sebagai akibat adanya kenaikan atau penurunan dari nilai variabel independen. Analisis ini juga berguna 
untuk mengetahui apakah antara variabel independen dan variabel dependen memiliki arah hubungan positif atau negatif.

1. Manajemen Laba Akrual

\section{Hasil Regresi Data Panel}

\begin{tabular}{|c|c|c|c|l|}
\hline \multicolumn{5}{|l|}{ Sample: 20162018} \\
\hline \multicolumn{5}{|l|}{ Periods included: 3} \\
\hline \multicolumn{5}{|l|}{ Cross-sections included: 25} \\
\hline Total panel (balanced) observations: 75 \\
\hline Variable & Coefficient & Std. Error & t-Statistic & Prob. \\
\hline C & 0.995222 & 0.093262 & 10.67128 & 0.0000 \\
\hline KM & -0.681518 & 0.058514 & -11.64703 & 0.0000 \\
\hline ROA & 0.312499 & 0.401148 & 0.779013 & 0.4399 \\
\hline DER & -0.149173 & 0.048256 & -3.091317 & 0.0033 \\
\hline
\end{tabular}

Sumber: Hasil olah data dengan Eviews9, 2019

Berdasarkan tabel 4.2 diperoleh regresi data panel sebagai berikut:

$$
\begin{aligned}
\mathrm{Y}_{1}= & 1.432392+1.171066 \mathrm{X}_{1}-4.103561 \mathrm{C}_{1}- \\
& 0.213820 \mathrm{C}_{2}+\varepsilon
\end{aligned}
$$

Keterangan:

$\mathrm{Y}_{1}=$ Manajemen laba akrual

$\mathrm{X}_{1}=`$ Kecakapan manajerial

$\mathrm{C}_{1}=$ Return on assets (ROA)

$\mathrm{C}_{2}=$ Debt to equity ratio (DER)

$\varepsilon “=$ Residual

Berkaitan dengan persamaan regresi diatas dapat dijelaskan sebagai berikut:

a. Konstanta (c) sebesar 1.432392, artinya apabila variabel kecakapan manajerial $(\mathrm{KM})$, return on assets (ROA), dan debt to equity ratio (DER) bernilai 0 maka nilai manajemen laba akrual sebesar 1.432392 .

b. Koefisien kecakapan manajerial (KM) sebesar 1.171066, artinya setiap kenaikan 1 satuan variabel kecakapan manajerial (KM) dengan asumsi bahwa variabel independen lainnya tetap, maka manajemen laba akrual akan meningkat sebesar 1.171066.

c. Koefisien return on assets (ROA) sebesar 4.103561, artinya setiap kenaikan 1 satuan variabel ROA dengan asumsi bahwa variabel independen lainnya tetap, maka manajemen laba akrual akan menurun sebesar 4.103561.

d. Koefisien debt to equity ratio (DER) sebesar 0.213820 , artinya setiap kenaikan 1 satuan variabel DER dengan asumsi bahwa variabel independen lainnya tetap, maka manajemen laba akrual akan menurun sebesar 0.213820 .

2. Manajemen Laba Riil

\begin{tabular}{|c|c|c|c|c|}
\hline \multicolumn{5}{|c|}{ Sample: 20162018} \\
\hline \multicolumn{5}{|c|}{ Periods included: 3} \\
\hline \multicolumn{5}{|c|}{ Cross-sections included: 25} \\
\hline \multicolumn{5}{|c|}{ Total panel (balanced) observations: 75} \\
\hline Variable & Coefficient & Std. Error & t-Statistic & Prob. \\
\hline $\mathrm{C}$ & 1.432392 & 0.337158 & 4.248429 & 0.0001 \\
\hline $\mathrm{KM}$ & 1.171066 & 0.338757 & 3.456949 & 0.0012 \\
\hline ROA & -4.103561 & 1.760409 & -2.331027 & 0.0241 \\
\hline DER & -0.213820 & 0.178197 & -1.199907 & 0.2362 \\
\hline
\end{tabular}

\section{Hasil Regresi Data Panel}

Sumber: Hasil olah data dengan Eviews9, 2019

Berdasarkan tabel 4.3 diperoleh regresi data panel sebagai berikut:

$\mathrm{Y}=0.995222-0.681518 \mathrm{X}_{1}+0.312499 \mathrm{C}_{1}-$ $0.149173 \mathrm{C}_{2}+\varepsilon$

Keterangan:

$\mathrm{Y}_{2}=$ Manajemen laba riil

$\mathrm{X}_{1}=$ Kecakapan manajerial

$\mathrm{C}_{1}=$ Return on assets (ROA)

$\mathrm{C}_{2}=$ Debt to equity ratio (DER)

$\varepsilon=$ Residual

Berkaitan dengan persamaan regresi diatas dapat dijelaskan sebagai berikut:

a. Konstanta (c) sebesar 0.995222, artinya apabila besaran variabel kecakapan manajerial (KM), return on assets (ROA), dan debt to equity ratio (DER) bernilai 0 maka nilai manajemen laba riil sebesar 0.995222 .

b. Koefisien kecakapan manajerial (KM) sebesar 0.681518 artinya setiap kenaikan 1 satuan variabel kecakapan manajerial (KM) dengan asumsi bahwa variabel independen lainnya tetap, maka manajemen laba riil akan menurun sebesar 0.681518 .

c. Koefisien return on assets (ROA) sebesar 0.312499 , artinya setiap kenaikan 1 satuan variabel ROA dengan asumsi bahwa variabel independen lainnya tetap, maka manajemen laba riil akan meningkat sebesar 0.312499 .

d. Koefisien debt to equity ratio (DER) sebesar 0.149173 , artinya setiap kenaikan 1 satuan variabel DER dengan asumsi bahwa variabel independen lainnya tetap, maka manajemen laba riil akan menurun sebesar 0.149173 .

\section{Pembahasan}

Manajemen Laba Akrual

1. Pengaruh Kecakapan Manajerial terhadap Manajemen Laba Akrual 
Kecakapan manajerial dalam penelitian ini diukur dengan Data Envelopment (DEA). Hasil penelitian menunjukkan bahwa kecakapan manajerial berpengaruh positif terhadap manajemen laba akrual pada perusahaan LQ45 di Bursa Efek Indonesia (BEI) periode 2016-2018 dengan nilai signifikasi sebesar $0.0012(<0.05)$ dan koefisien $\beta$ sebesar 1.171066, sehingga hipotesis pertama $\left(\mathrm{H}_{1}\right)$ diterima. Hal tersebut membuktikan bahwa dengan kecakapan yang dimilikinya, manajer cenderung melakukan aktivitas manajemen laba akrual karena komponen akrual mudah direkayasa sesuai dengan keinginan pribadi. Pada akhir periode ketika manajemen mengetahui bahwa taret laba tidak tercapai, maka manajer akan merekayasa discretionary accruals yang tidak berpengaruh terhadap arus kas secara langsung.

Hasil ini konsisten dengan penelitian Kirana, Hasan, dan Hardi (2016) yang menyatakan bahwa kecakapan manajerial berpengaruh positif terhadap praktik manajemen laba. Hal ini dikarenakan manajer yang cakap dapat memanfaatkan kewenangan untuk memilih kebijakan dalam proses penyusunan laporan keuangan yang memungkinkan manajer melakukan manipulasi informasi laba. Semakin cakap seorang manajer maka semakin tinggi manajemen laba yang dilakukan perusahaan. Begitupun dengan Puspita dan Kusumaningtyas (2017), dimana manajer yang memiliki tingkat kecakapan yang tinggi akan lebih terampil dalam mengolah informasi sehingga memberi peluang untuk melakukan praktik manajemen laba.

Namun, hasil ini bertentangan dengan penelitian Kodriyah dan Putri (2019) yang menunjukkan bahwa kecakapan manajerial tidak berpengaruh terhadap manajemen laba akrual, dimana manajer yang cakap mampu mengambil keputusan tepat sehingga dapat mencapai tingkat efisiensi yang tinggi dalam mengelola input agar output yang dihasilkan optimal. Manajer yang cakap lebih mempertimbangkan untuk terus meningkatkan kualitas kinerjanya sehingga meningkatkan nilai perusahaan, daripada melakukan tindakan manajemen laba yang dapat menghilangkan kepercayaan investor dan publik.

Hasil dalam penelitian ini menunjukkan bahwa manajer yang memiliki kemampuan dan integritas yang tinggi dapat melakukan tindakan oportunis seperti memanipulasi informasi yang disajikan pada laporan keuangan. Akrual adalah bentuk keputusan manajemen dibidang keuangan yang memberi nilai tambah bagi perusahaan. Manajer dengan keahlian yang dimilikinya, dapat memanfaatkan peluang pada keputusan akrual tersebut. Selain itu, adanya kesenjangan informasi dimana manajer memiliki informasi yang lebih banyak dibanding pemilik perusahaan mengenai aktivitas bisnis perusahaan mendorong manajer berperilaku oportunis dalam mengungkapkan informasi keuangan.

2. Pengaruh Return on Assets (ROA) sebagai Variabel Kontrol terhadap Manajemen Laba Akrual

Berdasarkan hasil penelitian dalam tabel 4.2 menunjukkan bahwa ROA sebagai variabel kontrol berpengaruh negatif terhadap manajemen laba akrual pada perusahaan LQ45 yang terdaftar di BEI periode 2016-2018 dengan nilai signifkasi 0.0241 $(<0.05)$ dan koefisien $\beta$ sebesar -4.103561 . Hal tersebut membuktikan bahwa dengan tingkat ROA yang tinggi, manajer tidak termotivasi untuk melakukan praktik manajemen laba karena kinerja perusahaan telah sesuai dengan ekspektasi yang diharapkan. Semakin tinggi ROA suatu perusahaan, maka manajer akan cenderung tidak melakukan manajemen laba karena akan mengurangi kredibilitas perusahaan.

Hasil ini konsisten dengan penelitian Picauly dan Sitohang (2017) yang menyatakan bahwa ROA berpengaruh negatif terhadap manajemen laba, dimana ROA yang tinggi mencerminkan kinerja perusahaan yang maksimal dalam menggunakan seluruh asetnya untuk menciptakan laba sehingga manajer tidak perlu melakukan praktik manajemen laba. Sebaliknya, manajer akan meningkatkan kualitas kinerjanya agar ROA periode berikutnya semakin meningkat, sehingga aktivitas manajemen laba dapat ditekan.

Namun, hasil ini tidak konsisten dengan penelitian Purnama (2017) yang menyatakan bahwa ROA berpengaruh positif terhadap manajemen laba. Hal ini karena dengan ROA yang tinggi manajer akan cenderung melakukan manajemen laba dengan pola income minimization untuk kepentingan perpajakan agar beban pajak yang dibayar menjadi lebih kecil dan income maximization untuk menciptakan kinerja perusahaan yang baik sehingga meningkatkan nilai perusahaan.

3. Pengaruh Debt to Equity Ratio (DER) sebagai Variabel Kontrol terhadap Manajemen Laba Akrual

Berdasarkan hasil penelitian dalam tabel 4.2 menunjukkan bahwa DER sebagai variabel kontrol berpengaruh negatif dan tidak siginifikan terhadap manajemen laba akrual pada perusahaan LQ45 yang terdaftar di BEI periode 2016-2018 dengan nilai signifkasi $0.2362(>0.05)$ dan koefisien $\beta$ sebesar -0.213820 . 
Hasil ini konsisten dengan penelitian Yunietha dan Palupi (2017) yang menyatakan bahwa leverage tidak berpengaruh terhadap manajemen laba. Hal ini karena leverage tidak menjadi penentu suatu perusahaan akan melakukan aktivitas manajemen laba, disebabkan dalam proses audit jumlah utang perusahaan dapat dikonfirmasi dan perusahaan dengan modal yang lebih besar berasal dari pinjaman akan diawasi lebih ketat oleh debitur sehingga perusahaan akan sulit melakukan manajemen laba.

Namun hal ini tidak konsisten dengan penelitian Fatmasari dan Supriyati (2016) yang membuktikan bahwa DER berpengaruh terhadap manajemen laba, karena semakin tinggi DER suatu perusahaan maka akan tinggi pula tindakan manajemen laba, artinya bahwa perusahaan memiliki utang yang tinggi dan untuk menutupi semua risiko yang terjadi, manajer cenderung melakukan manajemen laba melalui Debt Covenant Hypothesis (Hipotesis Ekuitas Utang). Hipotesis tersebut berpendapat bahwa semakin tinggi DER suatu perusahaan, semakin dekat perusahaan tersebut dengan batasan-batasan dalam perjanjian utang dan semakin besar peluang terjadinya pelanggaran perjanjian kontrak maka semakin besar kemungkinan manajer menaikkan laba melalui discretionary accrruals.

\section{Manajemen Laba Riil}

1. Pengaruh Kecakapan Manajerial terhadap Manajemen Laba Riil

Manajer yang memiliki kapabilitas dan keahlian yang baik dalam mengelola bisnis perusahaan dapat dikatakan sebagai manajer yang cakap. Hasil penelitian dalam tabel 4.3 menunjukkan bahwa kecakapan manajerial berpengaruh negatif terhadap manajemen laba riil pada perusahaan LQ45 di Bursa Efek Indonesia (BEI) periode 2016-2018, dengan nilai signifikasi sebesar $0.0000(<0.05)$ dan koefisien $\beta$ sebesar 0.681518 sehingga hipotesis kedua $\left(\mathrm{H}_{2}\right)$ diterima. Hal ini berarti semakin cakap seorang manajer, maka manajer cenderung tidak melakukan aktivitas manajemen laba riil.

Hasil ini konsisten dengan penelitian Mukhtar (2016) membuktikan bahwa kecakapan manajerial berpengaruh negatif terhadap manajemen laba riil. Semakin cakap seorang manajer dalam perusahaan cenderung untuk tidak melakukan praktik manajemen laba riil karena manajer berusaha meningkatkan kinerjanya akan memanfaatkan sumber daya perusahaan secara baik untuk menghasilkan laba yang optimal. Hal ini karena seorang manajer sebagai pengelola perusahaan ingin menyajikan laporan keuangan yang lebih baik daripada harus melakukan praktik manajemen laba yang memiliki dampak buruk bagi perusahaan.

Namun, hasil ini tidak konsisten dengan penelitian Lande dkk. (2014) yang menyatakan bahwa kecakapan manajerial berpengaruh positif terhadap manajemen laba riil, dimana manajer memproduksi persediaan dalam skala yang lebih besar dari yang dibutuhkan untuk memenuhi permintaan yang diharapkan perusahaan (overproduction) untuk meningkatkan laba tahun berjalan. Dengan tingkat produksi yang lebih tinggi, biaya overhead tetap per unit semakin kecil sehingga biaya per unitnya menjadi rendah. Oleh karena itu, biaya barang yang terjual lebih rendah sehingga perusahaan mendapat keuntungan operasi yang lebih baik.

Hasil penelitian ini menunjukkan bahwa manajer yang dianggap cakap cenderung tidak melakukan manajemen laba riil. Manajemen laba riil dilakukan dengan merekayasa angka laba melalui aktivitas operasional perusahaan yang dapat dilakukan kapan saja selama periode akuntansi baik melalui arus kas operasi abnormal, arus kas produksi abnormal, dan biaya diskresioner abnormal. Namun, manajer yang cakap akan meningkatkan kualitas kinerja dengan memanfaatkan sumber daya perusahaan, daripada harus melakukan praktik manajemen laba yang memiliki dampak buruk bagi kelangsungan usaha perusahaan. Manajer cenderung melakukan manajemen laba akrual dibandingkan manajemen laba riil, karena manajer yang cakap akan merekayasa komponen akrual ketika manajemen mengetahui bahwa target laba tidak tercapai. Berdasarkan penelitian Zang (2012) dan Masri (2018) terdapat hubungan substitusi antara manajemen laba akrual dan riil, dimana ketika manajemen laba akrual meningkat, maka manajemen laba riil menurun. Hal ini disebabkan manajer akan sulit memanipulasi laba pada aktivitas riil ketika kegiatan operasi perusahaan dipantau secara ketat oleh regulator dan investor serta memiliki kualitas audit yang baik.

2. Pengaruh Return on Assets (ROA) sebagai Variabel Kontrol terhadap Manajemen Laba Riil

Berdasarkan hasil penelitian dalam tabel 4.3 menunjukkan bahwa ROA sebagai variabel kontrol berpengaruh positif dan tidak signifikan terhadap manajemen laba riil pada perusahaan LQ45 yang terdaftar di BEI periode 2016-2018 dengan nilai signifikasi sebesar $0.4399(>0.05)$ dan koefisien $\beta$ sebesar 0.312499. Hal tersebut membuktikan 
bahwa dengan tingkat ROA yang rendah, mendorong manajer untuk melakukan praktik manajemen laba untuk menyelamatkan kinerjanya di mata pemilik sehingga manajer dapat memperoleh bonus.

Hasil penelitian ini konsisten dengan penelitian Kholifi (2018) yang menyatakan bahwa ROA memiliki pengaruh terhadap manajemen laba riil, dimana efektivitas perusahaan dalam menghasilkan laba melalui pengoperasian aktiva yang dimiliki menjadi tolok ukur kinerja perusahaan sehingga mendorong manajer untuk melakukan aktivitas manajemen laba.

Namun, hasil penelitian ini tidak konsisten dengan penelitian Wiyadi dkk. (2016) yang menyatakan bahwa ROA tidak berpengaruh terhadap manajemen laba. Hal ini disebabkan semakin tinggi ROA, maka dividen yang dibagikan semakin besar. Profitabilitas yang semakin meningkat mencerminkan kinerja perusahaan yang baik dan para pemegang saham akan menerima keuntungan yang besar pula. Selain itu, manajer akan mendapatkan keuntungan berupa bonus karena berhasil mencapai laba yang optimal sehingga tidak perlu melakukan manajemen laba.

3. Pengaruh Debt to Equity Ratio (DER) sebagai Variabel Kontrol terhadap Manajemen Laba Riil

Berdasarkan hasil penelitian dalam tabel 4.3 menunjukkan bahwa DER sebagai variabel kontrol berpengaruh negatif terhadap manajemen laba riil pada perusahaan LQ45 yang terdaftar di BEI periode 2016-2018 dengan nilai signifikasi sebesar sebesar $0.0033(<0.05)$ dan koefisien $\beta$ sebesar 0.149173 .

Hasil ini tidak konsisten dengan penelitian Dewi dan Wirawati (2019) yang menyatakan bahwa leverage berpengaruh negatif terhadap manajemen laba, dimana perusahaan dengan utang yang tinggi memerlukan bantuan dana dari pihak ketiga baik investor maupun kreditur. Untuk mendapatkan dana tersebut, perusahaan berupaya untuk mendapatkan kepercayaan dari investor maupun kreditur dengan mengurangi praktik manajemen laba.

Namun hasil penelitian ini tidak konsisten dengan penelitian Astari dan Suryanawa (2017) yang menyatakan bahwa leverage berpengaruh positif terhadap manajemen laba, karena leverage yang tinggi mendorong manajer untuk melakukan pengelolaan laba agar terhindar dari pelanggaran kontrak utang yang telah disepakati.

\section{KESIMPULAN DAN SARAN}

\section{Kesimpulan}

Berdasarkan hasil penelitian tentang pengaruh kecakapan manajerial terhadap manajemen laba akrual dan riil pada perusahaan LQ45 yang terdaftar di Bursa Efek Indonesia (BEI) periode 2016-2018. Dari hasil penelitian terdapat 25 sampel perusahaan perusahaan LQ45 periode 2016-2018 maka dapat ditarik kesimpulan sebagai berikut:

1. Kecakapan manajerial berpengaruh positif terhadap manajemen laba akrual. Hal ini berarti semakin tinggi kecakapan manajerial akan berdampak terhadap manajemen laba akrual yang dilakukan perusahaan. Manajer yang cakap memanfaatkan keahlian dan kemampuan yang dimilikinya untuk melakukan tindakan oportunis dengan merekayasa komponen akrual dalam laporan keuangan, sebab akrual adalah komponen yang mudah untuk direkayasa sesuai dengan keinginan pribadi. Manajer akan merekayasa discretionary accrual yang tidak berpengaruh terhadap arus kas secara langsung dan biasanya dilakukan pada akhir periode akuntansi ketika manajemen mengetahui bahwa target laba tidak tercapai.

2. Kecakapan manajerial berpengaruh negatif terhadap manajemen laba riil. Hal ini berarti semakin tinggi kecakapan manajerial maka manajer tidak melakukan manajemen laba riil. Manajer yang cakap cenderung meningkatkan kualitas kinerja dengan memanfaatkan sumber daya perusahaan guna mencapai tingkat efisiensi yang tinggi. Dengan kecakapan yang dimilikinya, manajer mampu membuat keputusan ekonomi yang tepat dan mencapai laba yang optimal sehingga manajer tidak perlu melakukan manajemen laba riil dengan merekayasa angka laba pada aktivitas operasional perusahaan baik melalui arus kas operasi abnormal, arus kas produksi abnormal, dan biaya diskresioner abnormal. Selain itu, jika kegiatan operasional perusahaan diawasi secara ketat oleh investor dan regulator serta memiliki kualitas audit yang baik maka manajer akan sulit melakukan memanipulasi laba pada aktivitas riil.

\section{Saran}

Berdasarkan kesimpulan diatas, beberapa saran yang perlu diperhatikan adalah sebagai berikut: 
Bagi Peneliti Selanjutnya, sebaiknya:

1. Menggunakan populasi perusahaan yang lebih besar, baik perusahaan yang bergerak dalam sektor lain maupun seluruh perusahaan yang terdaftar di Bursa Efek Indonesia.

2. Menggunakan periode pengamatan yang lebih panjang karena semakin lama interval waktu pengamatan maka semakin besar kesempatan untuk memperoleh informasi yang handal untuk melakukan penilaian yang akurat.

3. Menggunakan lebih banyak variasi variabel dalam penelitiannya, seperti corporate governance, earnings power, asimetri informasi, kualitas audit sebagai moderasi dan lainnya yang dapat digunakan untuk mendeteksi aktivitas manajemen laba akrual dan riil.

4. Menggunakan model yang berbeda dalam menentukan discretionary accrual, seperti Kanszik Model atau Performance-Matched Discretionary Accruals Model sehingga dapat melihat adanya manajemen laba akrual dengan sudut pandang yang berbeda.

\section{Bagi Perusahaan, sebaiknya:}

1. Memperkuat dan menerapkan peraturanperaturan serta mengadakan proses internal audit bagi manajer untuk mengurangi aktivitas manajemen laba akrual dan riil yang hanya memberikan kesejahteraan bagi pihak tertentu.

2. Menerapkan integritas manajemen yang tinggi untuk menghindari praktik manajemen laba akrual dan riil, karena manajer yang cakap dianggap memiliki kemampuan, integritas, dan keahlian yang baik sehingga dapat mengambil keputusan yang tepat demi tercapainya tujuan perusahaan.

\section{Bagi Investor dan Calon Investor, sebaiknya:}

Mewaspadai praktik manajemen laba akrual dan riil dengan menganalisa kondisi keuangan serta kinerja perusahaan dalam laporan keuangan sebelum membuat keputusan investasi, karena informasi keuangan yang disajikan belum tentu mencerminkan kondisi perusahan yang sebenarnya.

\section{DAFTAR PUSTAKA}

Astari, A. A. dan Suryanawa, I. K. (2017). FaktorFaktor yang Mempengaruhi Manajemen Laba. E-Jurnal Akuntansi, Universitas Udayana. Vol. 20, No. 1. Hal: 290-319.

Azizah, W. (2017). Opportunistic Perspective off Acrual and Real Earnings Management in
Indonesia. IOSR Journal of Business and Management. Vol. 19. Hal:1-5.

Banjarnahor, D. (2019). Laporan Laba Janggal, OJK Minta BEI Periksa Manajemen Garuda. http://www.cnbcindonesia.com. Diakses pada 14 Oktober 2019, pukul 10.00.

Cohen, D. A., Dey, A., dan Lys, T. Z. (2008). Real and Accrual-Based Earnings Management in the Pre- and Post-Sarbanes-Oxley Periods. The Accounting Review. Vol. 83, No. 3. pp. 757-787.

Cohen, D. A. dan Zarowin, P. (May 2010). Accrual-Based and Real Earnings Management Activities Around Seasoned Equity Offerings. Journal of Accounting and Economics. Vol. 50, No. 1. pp 2-19.

Dechow, P. M., Sloan, R. G., dan Sweeney, A. P. (1995). Detecting Earnings Management. The Accounting Review. Vol. 70, No.2. Hal: 193-225.

Dewi, P. E. dan Wirawati, N. G. (2019). Pengaruh Leverage Terhadap Manajemen Laba Dengan Corporate Governance Sebagai Variabel Pemoderasi. E-Jurnal Akuntansi Universitas Udayana. Vol. 27, No. 1. Hal: 505-533.

Gunny, K. A. (2010). The Relation Between Earnings Management Using Real Activities Manipulation and Future Performance: Evidence from Meeting Earnings Benchmarks. Contemporary Accounting Research. Vol. 27, No. 3. pp 855-888.

Kasmir. (2019). Analisis Laporan Keuangan. Edisi Kesebelas. Depok: PT Rajagrafindo Persada.

Kirana, R., Hasan, A., dan Hardi. (2016). Pengaruh Tingkat Pengungkapan Laporan Keuangan, Kecakapan Manajerial, dan Risiko Litigasi terhadap Manajemen Laba dengan Kualitas Audit sebagai Variabel Pemoderasi (Studi Empiris Perusahaan Manufaktur di Bursa Efek Indonesia periode 2011-2014). Jurnal Akuntansi, Magister Akuntansi Fakultas Ekonomi Universitas Riau. Vol. 4, No. 2. Hal: 189-204.

Kodriyah dan Putri, R. F. (2019). Pengaruh Perencanaan Pajak dan Kecakapan Manajerial terhadap Manajemen Laba. Jurnal Akuntansi, Universitas Serang Raya. Vol. 6, No. 1. Hal: 55-67.

Lande, A., Subekti, I., dan Mardiati, E. (2014). Pengaruh Tata Kelola Perusahaan, Kecakapan Manajerial, dan Rasio Leverage terhadap Manajemen Laba. Simposium 
Nasional Akuntansi 17, 24-27 September 2014, Mataram.

Masri, I. (2018). The Role of Corporate Governance in the Relationships of Family Company with Real Earnings Management. Jurnal Akuntansi. Vol. 22, No.1. Hal: 51-67.

Mukhtar, N. (2016). Pengaruh Earning Power, Kecakapan Manajerial, dan Employee Stock Ownership Program terhadap Manajemen Laba Riil (Studi Empiris pada Perusahaan Manufaktur yang Terdaftar di Bursa Efek Indonesia tahun 2010-2014). Jurnal Akuntansi. Vol. 4, No. 1. Hal: 10-12

Mulyadi. (2016). Aplikasi Data Envelopment Analysis pada Perbankan Indonesia. Edisi Pertama. Yogyakarta: Lintang Pustaka Utama.

Ponto, H. R. dan Rasyid, A. (2017). Pengaruh Kecakapan Manajerial, Rasio Leverage, dan Ukuran Perusahaan terhadap Manajemen Laba. Jurnal Manajemen dan Akuntansi, Universitas Yapis Papua. Vol. 5, No. 1. Hal: 8-19.

Pujiastuti, L. (2015). Kasus Skandal Keuangan, CEO Toshiba Mundur. http://finance.detik.com. Diakses pada 14 Oktober 2019, pukul 09.00

Purnama, D. (2017). Pengaruh Profitabilitas, Leverage, Ukuran Perusahaan, Kepemilikan Institusional dan Kepemilikan Manajerial terhadap Manajemen Laba. Jurnal Riset Keuangan dan Akuntansi, Universitas Kuningan. Vol. 3, No. 1. Hal: 1-14.

Puspita, E. dan Kusumaningtyas, D. (2017). Pengaruh Mekanisme Kepemilikan Manajerial, Kecakapan Manajerial, Tingkat Pengungkapan Laporan Keuangan terhadap Manajemen Laba dengan Kualitas Audit sebagai Variabel Intervening. Jurnal Ilmiah Efektor. Vol. 4, No. 2. Hal: 31-35.
Roychowdhury, S. (2006). Earnings Management Through Real Activities Manipulation. Journal of Accounting and Economics. Vol. 42, No. 3. pp. 335-370.

Sukamulja, S. (2019). Analisis Laporan Keuangan sebagai Dasar Pengambilan Keputusan Investasi. Edisi Pertama. Yogyakarta: ANDI dan BPFE.

Sulistyanto, S. (2008). Manajemen Laba: Teori dan Model Empiris. Edisi Pertama. Jakarta: PT Gramedia Widiasarana Indonesia.

Wiyadi, Trisnawati, R., Puspitasari, N., dan Sasongko, N. (2016). Pengaruh Asimetri Informasi, Leverage, dan Profitabilitas terhadap Manajemen Laba Riil pada Perusahaan Manufaktur di Indonesia. The 3rd University Research Colloquium, Hal: 93-107.

Yulivia, Y., Muslim, R. Y., dan Fauziati, P. (2016). Pengaruh Kepemilikan Insitusional, Kepemilikan Publik, Kompensasi Bonus dan Leverage terhadap Manajemen Laba (Studi Empiris pada Perusahaan Manufaktur yang Terdaftar di Bursa Efek Indonesia Periode 2010-2014). Jurnal Ekonomi. Vol. 2, No. 1. Hal: 2.

Yunietha, Y. dan Palupi, A. (2017). Pengaruh Corporate Governance dan Faktor Lainnya terhadap Manajemen Laba Perusahaan Publik Non Keuangan. Jurnal Bisnis dan Akuntansi, STIE Trisakti. Vol. 19. Hal: 292303.

Zang, A. Y. (2012). Evidence on the Trade-Off between Real Activities Manipulation and Accrual-Based Earnings Management. The Accounting Review. Vol. 87, No.2. pp 657703. 